\title{
A hard look at common law administrative tribunals
}

OÑATI SoCio-Legal Series Volume 11, Issue 2 (2021), 409-444: “ToO MuCh Litigation?”: FACTS, REASONS, CONSEQUENCES, AND SOLUTIONS

DOI LINK: HTTPS://DOI.ORG/10.35295/OSLS.IISL/0000-0000-0000-1150

RECEIVED 21 OCTOBER 2019, ACCEPTED 02 NOVEMBER 2020

\section{GUY I. SEIDMAN*}

\section{Abstract}

This paper looks at common law administrative tribunals. For legal-historical reasons, these bodies are located at the bottom of the judicial hierarchy or outside of it; its adjudicators often have less training, formal protections and resources than judges of the general court system, yet are required to handle a huge caseload. One difficulty is that administrative tribunals are often not part of the litigation data, skewing statistics. Another difficulty is more substantive: it makes sense for "lower courts" to be assigned cases traditionally considered less legally complicated and overall "less important"; yet common law administrative tribunals often deal with highly complex, socially sensitive legal issues with major potential consequences for litigants' rights such as bankruptcy, immigration or welfare. Not only should common law administrative tribunals be fully counted in court data, but they should also receive more resources and sufficient judicial oversight to ensure their good operation and litigants' rights.

\section{Key words}

Judges; litigation; administrative tribunals

\section{Resumen}

Este artículo se centra en los tribunales administrativos de derecho consuetudinario. Por razones jurídico-históricas, estas instituciones se ubican en lo más bajo de la jerarquía judicial, o fuera de ella; los jueces suelen tener menos preparación, protecciones formales y recursos que los jueces del sistema general de tribunales, pero se les exige gestionar un enorme número de casos. Una de las dificultades es que los tribunales administrativos no suelen ser parte de los datos de litigio, provocando unas estadísticas distorsionadas. Otra dificultad es más substantiva: es lógico que a los "tribunales inferiores" se les asignen casos tradicionalmente considerados menos

\footnotetext{
* Professor of Law, the Harry Radzyner School of Law, The Interdisciplinary Center (IDC) Herzliya, Israel. My thanks to the percipients of the workshop on Too Much Litigation? Facts, Reasons, Consequences, and Solutions held June 2019 in the International Institute for the Sociology of Law, Oñati, Spain, and especially to Eyal Katvan, Gary Lawson and the anonymous peer-reviewers of this paper. All translations from Hebrew are mine, unless otherwise stated. I welcome comments at: gseidman@idc.ac.il
} 
complicados y, en general, "menos importantes"; sin embargo, los tribunales administrativos de derecho consuetudinario suelen tener que ocuparse de casos jurídicos altamente complejos y sobre temas socialmente sensibles, con consecuencias potenciales muy importantes para los derechos de los litigantes, como por ejemplo la bancarrota, la inmigración o el bienestar. Los tribunales administrativos de derecho consuetudinario no sólo deberían ser considerados íntegramente en los datos judiciales, sino que también deberían recibir más recursos y una supervisión judicial suficiente para asegurar su buen funcionamiento y los derechos de los litigantes.

\section{Palabras clave}

Jueces; litigio; tribunales administrativos 


\section{Table of contents}

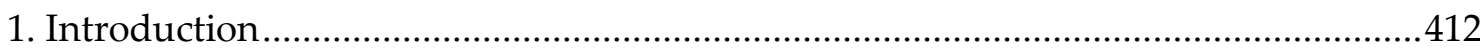

2. What is a court, who is a judge, and who is overworked?........................................415

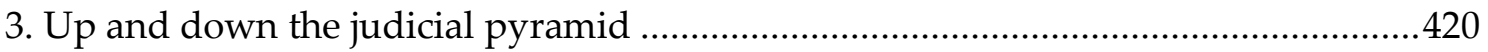

4. Common law administrative - Law \& administrative tribunals.................................423

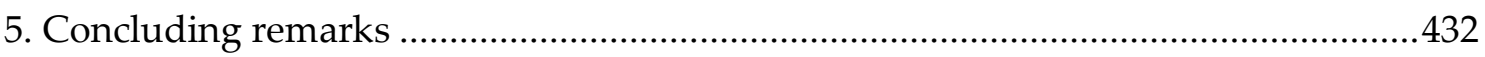

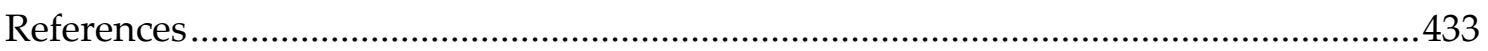

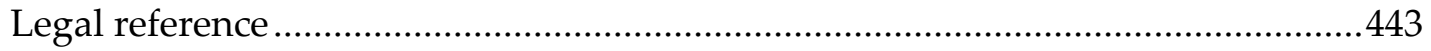

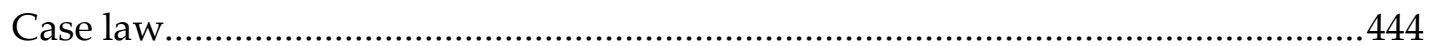




\section{Introduction}

The 2019 Oñati conference "Too Much Litigation?": Facts, Reasons, Consequences, and Solutions looked into the question whether there is "too much litigation", often raised in evaluating the functioning of judicial systems in national and comparative perspectives. Litigation levels are, indeed, a complex issue with many factors - social, economic, psychological and legal - to consider.

This paper is engaged with the preliminary stage - that of gathering and evaluating the data. Cleary, before we can engage in a substantive discussion of litigation levels, we must know the facts; we must establish a common ground, a shared understanding of the basic parameters of litigation levels and what exactly it is that we seek to measure. One might assume this to be a straightforward, almost technical matter of bean-counting. After all - how difficult can it be to find out how many courts and judges operate in any given jurisdiction and how many cases they hear per annum? The courts are a branch of government; judges are state employees, carrying out official duties and producing voluminous records.

Establishing a shared understanding of the core terms, common definitional baselines, turns out to be non-trivial. Several other papers in this volume also raise the issue, notably Lynn Mather (2021), who explains that even establishing what counts as "a case", clearly a basic building block in this context, proves complicated. Other core terms such as (what are) courts and (who are) judges - are similarly difficult to pin down. This is why serious efforts to collect all the relevant data for an informed discussion of litigation levels produce, as we shall see, complex, multi-factored tests, that require great resources to apply and are not met with universal acceptance.

There are some common conventions that provide "thumb rules" to help us in this process. Their shortcomings are that they offer approximations rather than definitional clarity and accuracy, and their unfortunate effect of virtually effacing common law administrative tribunals, trivializing their importance and that of the cases before them; this is the main point of this paper.

One such way looks at courts in terms of their typical form and function: we take a comprehensive look at the event taking place, and compare to what we expect to see at a judicial adjudication as we know it: are we looking at what looks like a courtroom? Are there two sides standing before a person, employing some form of procedure, considering their arguments and looking for a resolution? Is this adjudicator a state official and does she have the power to make a binding, enforceable decision in a legal dispute within her jurisdiction? If so, we are likely to agree that we fall within the conventional understanding of a court proceeding, and have no doubt that court, judge and caseload should be counted-in for the purpose of the "too much litigation" debate.

This first approach - if it "looks" like an adjudication, it likely is one - is somewhat simplistic in choosing form over substance and it smacks of assuming the conclusion since we are only looking for what we already know. This test is also likely to cut off administrative proceedings: adjudicators may be lay, they may not hold the title judge; the proceeding may be informal and take place in simple settings and there is typically only one private party side to adjudication, the state being the other (as it is also in criminal proceedings). 
Yet, it seems fair to ask this: even if administrative adjudication passed the first test should we make the effort to count all the proceedings it in our census, prepared for the "too much litigation" debate? Enter the second, more substantive, approach. I doubt anyone thinks we should count all judicial proceedings: does anyone consider all cases to be equal? Cases are neither humans nor stock. Each case represents a dispute that needs to be settled, rights to be decided, and in common law possibly law to be set. Each adjudication has a context, a content, potential impact. This means that we would be right to consider some cases more important, more deserving of discussion and analysis and other cases less important all the way down to a de-minimis level, where the effort to count them clearly outweighs the lessons we expect to learn from them.

Even if we are willing to focus on important cases, how do we decide what cases, adjudicators and fora are sufficiently important to be counted in? What are the parameters and how do we pursue this enquiry efficiently without conducting a detailed analysis of each adjudication? Here too we can lean back on long held conventions, taking into consideration the subject matter of the dispute, the sides to it, the meaning and impact of the litigation and, of course, the identity of the deciding court.

Given the highly hierarchical nature of the court system and the preeminent role of high courts, especially in common law, a strong argument can be me made to rank caseimportance on the basis of the judicial-decisionmaker's formal rank. Thus, one might argue that all cases decided by the highest court of a jurisdiction are, by definition, important. This intuition is particularly easy to make about common law Supreme Courts, although some of it applies to civil law courts as well. There are good reasons why most of the total attention given to courts - their holdings, reputation, makeup, workload - is focused on Supreme Courts. These are powerful institutions. Often the constitutional co-equals of the executive and legislature, they can make law through precedent (although the legitimacy of this practice is not unchallenged; Lawson 2007) and have powers of judicial review of administrative action and often of the constitutionality of statutes (Chandrachud 2015, Lustig and Weiler 2018). In both common and civil law, as we look up the judicial tiers, we find more prestigious and powerful judgeships; more experienced and better regarded appointees and better paid and more independent judges (European Commission for the Efficiency of Justice CEPEJ - 2018, pp. 121-124). Moreover, some Supreme Courts have control over their dockets. When courts - not litigants - choose what cases to hear, they signal that these are cases of likely of particular import (Bentata et al. 2019).

The reality is that few Supreme Court cases turn out to have major legal, economic or social impact and even when they do, the importance of a precedent takes years to be established. It often turns out that the 'second highest' courts are of no less practical import: U.S. Appeals Courts are very powerful precisely because the U.S. Supreme Court grants certiorari to only a tiny fraction of petitions; and the Constitutional Court of Germany is "often described as one of the most powerful and most admired courts in the world" (Hailbronner 2014). Some would even argue that first-tier trial courts, who effectively "control the facts" - if not the law - are important in their own right. The common cut-off tends to be below the three upper tiers of the general court system. That is where we find lower courts and tribunals. These adjudicators receive limited attention, the failsafe device being the availability of appeal or petition for review by the higher 
courts. Yet regarding administrative tribunals, I believe this approach misses out on what is, in actuality, is a highly important - and massive - docket.

Another conventional wisdom that helps distinguish "important" cases from lesser ones looks at the stakes involved from a traditional, society-wide perspective. This criterion is both common and easily applicable in private and criminal law cases: the more money sued, the more serious the alleged offenses (and the potential punishment) the more important the case and more justification to treat it seriously (e.g., in terms of the trial court with original jurisdiction over it). This standard makes sense, especially when comparing the extremes: a billion-dollar case is likely more complex and impactful than a one-dollar-case; a murder is more disturbing to the public peace than a petty theft. This seems a reasonable (if imperfect) approximation of centuries old societal values established in common law: life, liberty and property are our prime concerns.

One shortcoming of this thumb-rule is that it does not take full stock of the impact on the individual - one who stands to contractually lose, or had stolen his prized possession, nominally worth only one dollar. Even societies that factor-in fairness concerns - consider the Scandinavian income-based fine system, home to the $\$ 103,000$ car speeding ticket - still assume that money approximates import.

A second difficulty is that public law rights receive short shrift through such classifications. Administrative tribunals have long been classified somewhere between executive agencies and the "real" courts of the judiciary, as attested by the quixotic effort to define the "quasi-judicial". Recently recognized rights and property forms, created by constitutional and administrative law, are considered less important than traditional rights, and current law typically considers to extend to them, at best, the protection of the "due process" of law.

Put another way, it is easy to argue that small claims are unimportant cases and should not be counted when reporting civil cases, or that minor traffic violations are negligible, and should not be counted among criminal cases. Such cases typically do not raise complex legal issues or have major impact on individuals' rights, and, moreover, their large number might skew the statistics away from the smaller number of major cases. Now consider administrative courts.

Civil lawyers - is whose jurisdictions specialized tribunals and the administrative adjudication system are mostly on an equal footing with the general law courts - might find the following surprising: in common law, for legal-historical reasons, specialized tribunals, especially administrative tribunals (who originate in the executive branch, and often still belong to it) have been relegated to the bottom of the judicial hierarchy or placed outside of it entirely. The individual adjudicators are often less qualified and enjoy fewer formal protections than court judges yet are required, at the same time, to handle a massive caseload (one that often dwarfs that of the entire court system).

All of this would stand to reason if these tribunals only handled issues of minor importance. But often this is not so, and the import of their cases, at least in terms of their significance to litigants (often the underprivileged classes of society) tends to be overlooked. Perhaps this has to do with the late establishment of administrative law, as a legal field, in common law or because these tribunals deal with more recently recognized public law rights. Be it as it may, the result is that administrative tribunals 
have been so marginalized that most people may not realize that much of their caseload - be it bankruptcy, education, housing, social entitlement and care or immigration and asylum - simply cannot be considered as minor by any account. In terms of legally complexity and the threat to human rights and liberties (often even to classically protected life, liberty and property interests), such cases are clearly important enough to be counted-in, discussed and analyzed in considering litigation levels; they are also important enough for common law countries to lavish on them more resources, ensuring professional standards befitting "important" cases.

Hence the twin goals of this paper: to argue for greater exposure of common law administrative tribunal casework in the "too much litigation" debate, especially when it is held in comparative perspective, and a call for more scholars and policy makers to reevaluate the status of such tribunals and allocated them more resources. To do so, this paper presents the essential facts and history of common law administrative tribunals in the context of the "too much litigation" debate. Part 2 notes two preliminary, definitional, difficulties of the "too much litigation" debate: the fact that most courts face heavy caseloads and that the term "adjudicator" can bear a very broad meaning. How much then, is too much? Who exactly is considered a judge and be counted-in? Conscious value judgments are needed to decide how to define, measure and limit the expanse of each term. Part 3 looks at the hierarchical divide among courts providing data of judicial caseload in both high courts, on among lower courts and tribunals; Part 4 relates how common law administrative courts came to be and explains how their comparativelegal-history resulted in their low status. It also looks at recent developments in administrative courts, in different jurisdictions, evaluating their current status. The conclusion, Part 5, is that while there is rising awareness of the importance and high caseload of administrative tribunals in common law jurisdictions relief measures are still far off, with the English model showing the most promise.

Finally, this paper provides data and examples from various common and civil law jurisdictions at different times in their history. Despite my best efforts, inaccuracies likely remain, especially relating to the precise jurisdiction of courts and tribunals in each part of the UK. I regard Israel as a common law jurisdiction, like England, Australia and UK, although I am aware that many scholars view Israel as a mixed jurisdiction (Rivlin 2012).

\section{What is a court, who is a judge, and who is overworked?}

\section{a. Adjudicators' big-tent}

When we try to survey all the officials who have the power of adjudication in all branches of government, we run a very wide gamut. It begins with judges and courts who look and operate exactly like we have learned to expect from popular culture, academic study or personal experience. In common law you can expect to see legally educated, robed judges, sitting on an elevated dais in a formal court room, adjudicating legally represented adversaries according to formal procedures. They control the court room, make binding decision decisions, executed by the State. Civil law adjudication bears many of these traits as well.

But when we look below the high courts, into lower tier courts and administrative tribunals, entities with judicial power who have more work and less resources than their senior colleagues, a somewhat different picture emerges. This is especially the case with 
administrative tribunals: such entities, whether termed tribunals, commissions, boards etc., may be constituted of lay government bureaucrats, empowered to decide on complaints against government. Often exempt from strict rules of procedure and evidence, they are more "quasi" than "judicial" and, in both form and substance, may be a far cry from what we have in mind when we proudly think of court protection of human and civil rights (Flores 2019).

There are legitimate practical and normative reasons to explain why modern legal systems offer such a variety of adjudicatory functions, and there are also various ways to help them prevent a miscarriage of justice or correct a wrongdoing. Lay judges are often expert in their relevant fields, and can avail themselves of legal advice; tribunals need exemption from formal rules of evidence and procedure to allow them functional elasticity; errors of judgment can typically be corrected on appeal to the law courts. Yet some aspects remain too vague: first, it is easier to describe the full range of entities that have judicial powers - it is more difficult to decide which of them court as courts and judges, especially in comparative perspective. As Ramseyer and Rasmusen (2013) note: "measuring the number of judges" in English courts "is not as simple as it seems, since 'judge' is an ambiguous term". A good demonstration of how this occurs and why it matters can be made through the European Report (CEPEJ 2018), shortly. The second is that the burden on most courts, in civil and common law, is so heavy, that the enormous burden of administrative tribunal does not looks all that exceptional, alarming or in need of urgent repair.

\section{b. We are all so very busy}

It seems like all judges of all legal systems, feel that they are overworked and struggle to deal with their annual caseload; in fairness, most do handle a large and complex caseload (Bendery 2015, Teller Report 2019). Shnoor and Katvan (2017) suggest that only recently have judicial system started to make their discomfort public, having preferred earlier "to preserve an ideal image of the judiciary and control all information about it". Indeed, in many jurisdictions, in common and civil law alike, court cases have become "stock", of which there is always a backlog that cannot be overcome. A Sisyphean task. Judges feel they work a conveyor belt with their efficiency, a.k.a. "clearance rate" rather than their professionalism, good judgement or compassion measured (Kleiman et al. 2017).

Take, for example, France's highest law court, the Cour de cassation. It presents in its annual report data of its case "stock": new cases enter (22,890 in 2017), cases are handled $(20,667)$, a huge backlog remains $(24,256$ cases, well over a full year's work; Cour de cassation 2018). Much the same can be said of the Israeli court system. Perhaps, as common law judges, the Israeli judges deserve a little more sympathy since, unlike their French counterparts, they conduct oral hearings and are required not only to make a decision but also to provide a clear explanation. On the other hand, they do find ways to dispose of most cases without an extensive and detailed written holding.

In 2018, a total of 854,196 cases were opened in the Israeli Court System (including the labor tribunals) (a 5\% rise over 2017), and 841,808 cases were closed. This is a robust clearance rate of $98.5 \%$ yet a backlog of 471,839 cases remained (Israeli Court System 2018, pp. 5, 7 and 8). Court System Director judge Marzel stressed that the number of cases opened in Israel annually represents "an average ratio of cases per judge that is high compared with other countries, while the figure of the number of judges compared 
with population size is also at a relative low ratio compared with that of no few countries". (Israeli Court System 2018, 5). Indeed, the judge-per-population-ratio in Israel is so low, that an eminent Israeli scholar recently proclaimed that "[i]n Israel the shortage of judges that has worsened over the years has led to a serious deterioration in the operation of Israel's judicial system" (Zer-Gutman 2019).

The Israeli Court System has been making this argument for some years, often in comparative perspective (Zarchin 2011). I believe they were citing the European report (current or earlier editions), to which Israel provided official data, and in which the Court System found ample support for its contentions. The European report carries weight. In a field where data it limited, it provides concrete, official data, reported by dozens of nations; it is compiled by a reputable, professional, neutral official entity - the Council of Europe's European Commission for the efficiency of justice - which made an effort to verify the quality of the data provided to it (CEPEJ 2018 - the European report -, p. 6; for other reports see: Decker et al. 2011 and European Commission 2019, also Onțanu and Velicogna 2021).

Moreover, the report makes a genuine effort to bridge the divide between civil and common law and provide relevant comparative data, by using a unitary institutional vocabulary especially in defining who is a judge, a difficult task, as noted. While the European report makes the effort, I am not sure it succeeds on this front, especially when it comes to common law courts and judges who fall below the top tiers of the general court system. Marco Fabri (2017) has detailed the methodological shortcomings of the European report, especially on the issue of how to define judges, and then consistently and accurately apply the definition. I wish to follow up with several observations, using tables that draw data from the European report: one table, draws on the categories and number of judges (CEPEJ 2018, p. 103); the second draws on data of the number of first instance, incoming and resolved, civil and commercial litigious cases per 100 inhabitants (CEPEJ 2018, p. 245):

TABLE 1

\begin{tabular}{|c|c|c|c|c|}
\hline \multirow[t]{2}{*}{ Jurisdictions } & \multicolumn{2}{|c|}{ Number of Professional judges } & \multicolumn{2}{|c|}{$\begin{array}{l}\text { Number of lay judges (gross } \\
\text { figures) }\end{array}$} \\
\hline & $\begin{array}{l}\text { Absolute } \\
\text { number }\end{array}$ & $\begin{array}{l}\text { Per 100,000 } \\
\text { inhabitants }\end{array}$ & $\begin{array}{l}\text { Absolute } \\
\text { number }\end{array}$ & $\begin{array}{l}\text { Per 100,000 } \\
\text { inhabitants }\end{array}$ \\
\hline France & 6,995 & 10 & 24,925 & 37 \\
\hline Germany & 19,867 & 24 & 91,717 & 112 \\
\hline Italy & 6,395 & 11 & 3,522 & 6 \\
\hline Spain & 5,367 & 12 & 7,692 & 17 \\
\hline England \& Wales & 1,760 & 3 & 16,296 & 28 \\
\hline Scotland & 200 & 4 & 450 & 8 \\
\hline Israel & 735 & 9 & 440 & 5 \\
\hline
\end{tabular}

Table 1. Categories and number of judges (2016). 
TABLE 2

\begin{tabular}{|l|c|c|}
\hline \multirow{2}{*}{ Jurisdictions } & \multicolumn{2}{|c|}{$\begin{array}{l}\text { Number of first instance civil and commercial litigious cases 100 } \\
\text { inhabitants in 2016 (Q1, Q91): }\end{array}$} \\
\cline { 2 - 3 } & Incoming Cases & Resolved Cases \\
\hline France & 2,5 & 2,5 \\
\hline Germany & 1,6 & 1,6 \\
\hline Italy & 2,6 & 2,9 \\
\hline Spain & 2,1 & 2,2 \\
\hline UK \& Scotland & 1,7 & 1,3 \\
\hline Israel & 4,8 & 4,6 \\
\hline
\end{tabular}

Table 2. First Tier Civil and Commercial Litigation Rates (2016).

b. Who is a [professional] judge?

The European report seems to support the general proposition that common law jurisdictions have fewer professional judges than civil law jurisdictions as well as the more specific notion that Israeli judges have a higher caseload than their colleagues of other all legal systems.

Is this really the case? I have great respect for the European report, and appreciate the effort that was required to bring it about. Yet I think there may be methodological explanations for the statistical differences in the number of judges both between civil and common law and among civil law jurisdictions. One issue is that the report is based on official data provided by each nation. If there was a team of researchers doing a stateby-state-census, we might have had more uniform results. Secondly, differences between civil and common law data may stem from the definitions used by the report, which clearly had civil law jurisdictions in mind.

The European report takes two definitional steps in explaining whom they define as "a judge":

First, it defines a judge, in light of the European Convention on Human Rights and the case law of the European Court of Human rights, as "a person entrusted with giving, or taking part in, a judicial decision opposing parties who be either legal or natural persons, during a trial" (CEPEJ 2018, p. 93). Using the term "a judicial decision" to define "a judge" is somewhat tautological, but what we can glean from it, at the very least, is that a judge is a person who has the official power to make a binding decision between two opposing sides after a procedure is undertaken.

But what type of judge exactly did the European report have in mind? It turns out that in order " $[\mathrm{t}] \mathrm{o}$ better take into account the diversity in the status and functions which can be linked to the word 'judge', three types of judges have been defined in the CEPEJ's scheme, according to an uncited 'proven typology'" (CEPEJ 2018, p. 93).

The first category is of "professional judges" who "can be defined as those who are recruited, trained and are remunerated to perform the function of a judge as a main occupation" (CEPEJ 2018, p. 101). Their "main function is to work as a judge and not as a prosecutor" (an observation more relevant to civil than common law jurisdictions; 
CEPEJ 2018, p. 93). The report notes that they include both full time and part time judge - but not professional judges "sitting on an occasional basis": (CEPEJ 2018, pp. 93, 101) such persons, "professional judges who practice on an occasional basis and are paid as such" constitute the second category (CEPEJ 2018, p. 93). Finally, the third category includes "non-professional judges who are volunteers, are compensated for their expenses and give binding decisions in court" (CEPEJ 2018, p. 93).

While the report attempts to explain how each category applies in the countries covered in it, including common law jurisdictions (CEPEJ 2018, pp. 101-102) this alleged "proven typology" seems to me less pertinent to common law jurisdictions, where experienced lawyers are tapped to be judges, and rarely 'trained' and where there is no confusing judges and prosecutors.

This seems to me clearly the case in Israel, where there seems to be an underreporting of full-time professional judges. According to the European report there are 735 professional and 440 lay judges in Israel. Who are they? I have a good guess as to the first figure: we reach it when we combine official figures for the total number of judicial positions for the three tiers of Israel's general court system plus the two tiers the labor courts (Israeli Court System 2018, p. 10, Central Bureau of Statistics 2018).

I am not clear about the latter figure, how it was drawn and which adjudicators it includes. But even on the former figure I have some reservations. I think it does not cover all Israeli officials who functionally - if not always formally - fall under the European report's definition of judges. At least four categories spring to mind: One: the general court system employs about 80 registrars, who are functionally and, when appointed as senior registrars, even formally, the equivalent of judges (Israeli Court System 2018, p. 12, The Courts Law (Consolidated Version) 5744-1984, §§ 84-103). Two: the judges of the labor courts are clearly reported among the professional judges. I see little reason why not to include the judges of other major tribunals, such as the ca. 20 full time professional jurists of the military tribunal system. There is limited data on religious judges in Israel. What we know is that the two-tiered Rabbinical courts alone has ca. 100 judges (Central Bureau of Statistics 2018). They may not be jurists, but they all have the required professional qualifications to decide under their applicable religious law and the state power to adjudicate. Thus, a strong case could be made for their inclusion as professional judges for the purposes of the European report. Three: in January 2009, Israeli established the Law Enforcement and Collection Authority, as an auxiliary unit of the Ministry of Justice (LEACA). This government agency employs ca. 70 registrars, who need to have the qualifications for appointment as magistrates, and whose carry out adjudication on matters of debt collection and execution of judgements that are make them clearly the functional equivalent of judges. Four, the Israeli Court system is empowered to enlist retired judges, up to the age of 75 . These judges can add up to $15 \%$ to the number of judicial positions yet they too, like the previous three categories are uncounted and unreported as full time professional judicial positions in Israel (https://he.wikipedia.org/wiki/שופט עמית).

It is worth noting that Australia uses the term "judicial officers": who are persons who "can make enforceable orders of the court," including "judges; associate judges; magistrates; masters; coroners; judicial registrars; all other officers who, following argument and giving of evidence, make enforceable orders of the court" (Australian 
Government Productivity Commission 2018, at Box 7.3). By this measure, the number of full-time judicial officers per 100,000 people in Australia in 2016-2017 was 4.4 - close to figure in the UK and much lower than the figure in Israel (Australian Government Productivity Commission 2018, at Table 7.5).

Another idea taken up by the European report is that "[t]he quality and efficiency of justice depend largely on the systems for the recruitment of judges, but also on their initial and continuous training, their number, the status which must guarantee their independence" and the number of staff supporting them (CEPEJ 2018, p. 95). These notions too, seem somewhat less relevant regarding common law judges.

I find merit in the definitions used by the European report, and doubt if I can improve on them much. What I am suggesting is that the definitions used were written with civil law judges in mind - quite reasonable, given that most nations covered by the report are civil law jurisdictions. They do not apply as well to common law judges, especially to lower tier judges and administrative adjudicators. This also explains under-reporting by national authorities of common law judgeships.

\section{Up and down the judicial pyramid}

\section{a. Upstairs, downstairs}

Another aspect of assessing judicial caseloads is the divide between higher and lower tiers. As a thumb rule that the higher up the judge, the less cases she hears; yet such cases are considered important, and merit more attention and greater resources. Once you reach the lowest tiers - especially administrative tribunals - the caseload is huge, resources scant and public interest minimal.

Much of this is a necessary result of judicial design. Court systems are very hierarchical. Judges are promoted up the ladder and higher tiers have the power to review lower-tier rulings. The higher-up the court, the greater its jurisdiction and power to set the law. Finally, since not every case is appealed, the number of cases decline significantly as you go up the pyramid - potentially up to a Supreme Court, standing at the apex, and more significantly so when the Supreme Court generally has to grant certiorari for cases to reach it (e.g. U.S. Constitution, Article III, Calabresi and Lawson 2007).

While these points are easy to demonstrate in the data (below), other issues are harder to explain: where exactly is the cut-off between high and low courts? What principle guides the division of labor, that leaves the lower courts with disproportionally more work than senior courts? Is it the importance of the court or that of the case? How did administrative law cases, tribunals and adjudicators end up at the bottom of the pack?

Sometimes the division between high and low courts is a matter of political design; sometimes it's a matter of judicial hierarchy. The result is often similar: quantitatively speaking, most judicial work is performed by lower tiers. Thus, while it may be true that in the United States, "important" cases go before the federal courts - hence the idiom "don't make a federal case out it" - that fact is that "[a]pproximately 95 percent of all legal cases initiated in the United States are filed in the state courts" (Goodnow 2011). This also has to do with the American Constitutional design, which gives the federal government limited, enumerated, power and leaves most legal issues to the States. Another example is England and Wales which have a long tradition where "Magistrates, 
or Justices of the Peace" who "are members of the local community without legal background or knowledge (...) act as judge in magistrates' court (...) working part-time and dealing with over 95\% of all criminal cases" (Judicial Office International Team 2018).

Some of the rationales for deciding at what tier a case must be filed at concerns traditional understandings of what is "important" such as the money sum at stake (in civil cases) or the gravity of the alleged offense (in criminal cases). Matters get more complicated in public law. Here, administrative law litigation is shipped wholesale to specialized low tier tribunals. More on the latter issues in Part 4.

\section{b. Data on the workload of the senior courts}

Here is data on the workload of the clearly identifiable senior three-tier court systems in several common law jurisdictions.

As noted, common law Supreme Courts tend to be the least "burdened" (in terms of the number of cases they hear per year). During the 2013 to 2017 terms, the number of cases argued before the U.S. Supreme Court ranged from 69 to 82, and the number of cases disposed of by full opinions by the nine Justices ranged from 63 to 75 (United States Courts 2017). The English Supreme Court is not far off: in the year ending March 31, 2018, the Court reports sitting for 95.5 days [sic!], its dozen members producing 78 judgments (Supreme Court of the United Kingdom (UKSC) 2018, Table 2). The Australian High Court reported that during the year ending June 30, 2018 its seven Justices handled 77 appeals and 166 case of original jurisdiction that are generally handled by a single Justice (High Court of Australia 2018, pp. 22, 24). The outlier is the Israeli Supreme Court: with limited control over its docket, it serves as both the main national court of appeals and as court of first instance (!) for many public law petitions. In 2018, its fifteen Justices dealt with 4,162 cases in three Justice-panels: 909 civil appeals, 717 criminal appeals, and the rest public law cases in original or appellate jurisdiction; a further 5,887 cases were dealt by a single Justice, reaching a whopping total of 10,049 cases (Israeli Court System 2018, p. 13).

Lower courts within the classic three tier central court system heard significantly more cases:

- In the United States (year ending September 30, 2018) the 13 Courts of Appeals dealt with 50,428 cases (United States Courts 2018b) and the 94 District Courts dealt with 276,311 civil and 79,866 Criminal cases (United States Courts 2018c, 2018d).

- In England, data shows that while the House of Lords - now the Supreme Court - dealt with 30 to 116 cases per year over the years 2006 to 2016 (Royal Court of Justice of the United Kingdom 2017, Table 3.1), the Court of Appeals' caseload was significantly higher: over the years 2004 to 2017 the Civil Division saw an increase from 1,059 (2004) to 1,298 (2011) before the number dropped to 938 (2017); the Criminal Division has seen a long-term decline from 7,591 cases (2004) to 5,411 (2017); the first tier High Court, also saw major fluctuations in caseload: the Administrative court saw a huge increased form 6,612 (2004) to a peak of 15,621 (2009), before a decline to 5,920 (2017); the Queen's Bench Division (QBD) saw a more limited fluctuation from a low of 3,841 cases (2005) to a high of 5,349 
(2014), then down again (to 4,319 cases in 2017); the family division saw a surge from 3,706 cases (2004) to 4,954 (2011), then a steep decline to 938 cases (2017) (Royal Court of Justice of the United Kingdom 2017, Table 3.1).

- Finally, in Israel, the District Courts dealt in 2018 with 65,509, and the Magistrates' Courts, 709,947 cases (Israeli Court System 2018, pp. 15, 23).

Large as these numbers seem, they only represent a fraction of all the adjudicatory effort conducted within each jurisdiction. The caseload of the top (typically three) tiers reflects the condition "upstairs," in the senior courts within each system. Sometimes courts are even officially designated as senior and subordinate, as in the UK, with a clear delineation between the two (Courts of England and Wales 2020, Crown Court 2020, Judiciary of Australia 2020, Judicial Office Communications Team n.d.-b). To understand the total caseload dealt with annually we need to look at lower courts. These are often (but not always) staffed by professional jurists, who carry heavy work burdens but do not enjoying the administrative support, pay or independence of senior judges, nor interest of the public and academia.

\section{c. The Workload of the Lower Courts (and administrative tribunals) - England}

Of these downstairs courts many are understandably considered "lower" courts by virtue of their limited jurisdiction (in term of the maximal sum they can adjudicate in civil suits and the penalties they can mete out in criminal suits). In the English Court system (for which the fullest data is available), the most common subordinate courts include - (1) the County Court - a national court of purely civil jurisdiction, sitting in 92 locations; (2) the Family Court - a national court, which sits in many locations and currently has general jurisdiction to hear family cases all over England and Wales; (3) Magistrates' and Youth Courts: The former are the first tier for minor criminal cases (and certain licensing appeals). They are presided by lay justices of the peace, or a legally trained district judge sitting - without jury - in each local justice area. The latter are similar courts, dealing with offenders aged 10 to 17 (Subordinate Courts, in Courts of England and Wales 2020). Almost needless to say, these courts handle the majority of the caseload: in 2017, Magistrates' courts in England and Wales received 1.5 million cases and Crown Courts received 114,000 cases. County Courts received 2.05 million claims and Family Courts received 255,000 (they also had a massive backlog of 297,000 outstanding cases in the Magistrates' court and 38,000 in the Crown Courts; Sturge 2018).

There is another category of lower courts - the administrative tribunals. Writing in 1993, Dame Hazel Genn described the incoherent nature of the English tribunal system, which had 50 different types of tribunal (and a total of around 2,000 tribunals). These tribunals operated with no common procedure or general appeal process; the members of some were lay - of others specialist. "Some tribunals" she noted, "act in a strictly judicial fashion, while others look more broadly at policy considerations. It is, in fact, impossible to provide a simple definition of a tribunal". The main reason for this state, explained Genn (2013), was that "such tribunals were historically "viewed as cheap, non-technical substitutes for the ordinary courts for a wide range of grievances and disputes, in which parties can initiate actions without cost or fuss".

Only recently, in 2007, did England reorganize and unify its tribunal and streamlined their operation - more on this in Part 4 - but the fact remains, that these tribunals conduct 
a huge part of cases in England: there is a first tier, divided into seven chambers (social entitlement; immigration and asylum; health, education and social care; war pensions and armed forces compensation; tax; general Regulatory; and land, property and housing) and an Upper Tribunal divided into four chambers (administrative appeals; immigration and asylum; tax and chancery; and Land) (Carnwath 2011), and the number of cases they hear is quite substantial as the following table indicates (selected data of cases disposed of per financial year (FY) - April 1, to the following March 31 - in English $1^{\text {st }}$ tier and upper $\left(2^{\text {nd }}\right)$ tier tribunals) (Ministry of Justice 2019, HM Courts \& Tribunals Service 2019).

TABLE 3

\begin{tabular}{|c|c|c|c|c|c|c|c|}
\hline FY & $\begin{array}{c}\text { Tribunals } \\
\text { Overall }\end{array}$ & \multicolumn{2}{|c|}{$\begin{array}{c}\text { Immigration \& } \\
\text { Asylum } \\
1^{\text {st }} \text { Tier } \mathbf{2}^{\text {nd }} \text { tier }\end{array}$} & \multicolumn{2}{|c|}{$\begin{array}{c}\text { Employment } \\
1^{\text {st }} \text { Tier 2 }\end{array}$} & $\begin{array}{c}\text { Social } \\
\text { tier } \\
\text { Security } \\
\text { \& Child } \\
\text { Support }\end{array}$ & $\begin{array}{c}\text { Mental } \\
\text { Health }\end{array}$ \\
\hline $\mathbf{2 0 0 7 / 0 8}$ & 550,147 & 172,093 & & 81,857 & 666 & 253,161 & 18,299 \\
\hline $\mathbf{2 0 0 8 / 0 9}$ & 568,671 & 183,307 & & 92,018 & 604 & 243,260 & 24,485 \\
\hline $\mathbf{2 0 0 9 / 1 0}$ & 649,917 & 207,354 & & 112,364 & 575 & 278,327 & 25,251 \\
\hline $\mathbf{2 0 1 0} / 11$ & 726,937 & 162,204 & 7,316 & 122,792 & 2,001 & 379,229 & 26,663 \\
\hline $\mathbf{2 0 1 1} / \mathbf{1 2}$ & 748,818 & 132,649 & 9,073 & 110,769 & 2,217 & 431,943 & 28,382 \\
\hline $\mathbf{2 0 1 2} / \mathbf{1 3}$ & 749,283 & 98,733 & 9,560 & 107,420 & 2,155 & 463,846 & 29,287 \\
\hline $\mathbf{2 0 1 3 / 1 4}$ & 878,007 & 100,122 & 8,902 & 148,387 & 1,684 & 543,609 & 31,614 \\
\hline $\mathbf{2 0 1 4} / \mathbf{1 5}$ & 649,068 & 91,421 & 8,654 & 312,773 & 1,392 & 150,978 & 31,971 \\
\hline $\mathbf{2 0 1 5} / \mathbf{1 6}$ & 372,929 & 69,696 & 8,066 & 49,529 & 1,055 & 156,535 & 33,286 \\
\hline $\mathbf{2 0 1 6} / \mathbf{1 7}$ & 394,103 & 69,184 & 7,393 & 45,177 & 905 & 190,071 & 33,936 \\
\hline $\mathbf{2 0 1 7} / \mathbf{1 8}$ & 407,640 & 64,265 & 6,979 & 38,671 & 905 & 214,478 & 32,981 \\
\hline $\mathbf{2 0 1 8} / \mathbf{1 9}$ & 401,885 & 59,353 & 8,245 & 43,431 & 1,083 & 207,572 & 33,251 \\
\hline
\end{tabular}

Table 3. English tribunal caseload.

In short, "[t]he delivery of administrative justice through tribunals comprises perhaps the largest part of the contemporary legal system (...). In short, tribunals are 'big business'" (Elliott and Thomas 2012). Which raises the question - how did this arrangement come to be - that a tiny part of administrative cases are dealt by the higher courts - and the huge majority of cases are dealt by a dense web of administrative tribunals. My best explanation is set in a long set common-civil law historic divide.

\section{Common law administrative - Law \& administrative tribunals}

a. Perhaps the deepest common-civil law divide?

Comparativist focus on the two main Western legal traditions - common and civil law. Historically, attention was on the differences between the two, but in recent decades growing cooperation has brought notice to the similarities between them, so that today we engage in a divergence - convergence debate (Merryman 1981, Funken 2003, Lundmark 2012, Pargendler 2018). Courts are a good example for this: common law systems typically have one general court system, authorized to set precedent. There may be specialized courts and tribunals (Aronson 2010), but the highest Court has final say over all adjudicators. In civil law jurisdictions we find a central court system, but also 
specialized courts (including administrative courts), which are not subject to it, and whose adjudicators are often not jurists. On the other hand while civil law courts traditionally did not have the formal power to make law, we now see changes: recognition of the significance of high court holdings, the power of some continental courts (national constitutional courts ) to set precedent, and then there are EU Courts, with the supreme and final power over common and civil law jurisdictions, among them the progenitors of both - the UK (until Brexit, likely only Ireland in the future), Germany, France, Italy and Spain (Randma-Liiv and Connaughton 2005).

Administrative adjudication is a prime example of the deep differences between common and civil law. It goes well beyond structural differences (having an independent court system, parallel to the general one, like Germany does (Bundesverwaltungsgericht, see https://www.bverwg.de/en) or professional differences (having non jurist adjudicators: German administrative courts panels are made up of professional and lay judges (Singh 2001, pp. 192-195): even common law jurisdictions allow for separate, specialized courts and tribunals, with lay judges (always subject to court review). The Administrative Appeals Tribunal Act (1975) sets up the specialized administrative courts of Australia, headed by members of the professional judiciary and widely staffed with lay judges in full or part time positions (Administrative Appeals Tribunal - AAT - n.d.). The schism runs much deeper. The best example is the distinction between English and French models of administrative law and adjudication.

England boasts a long evolution of political and judicial control over the royal administration (Seidman 2005). A major steppingstone were the writs of certiorari and mandamus. Developed between 1600 and 1750, these writs gave aggrieved subjects quicker and easier relief from illegal action by officials (Henderson 1963).

In contrast, in France, Administrative law began with the revolution. "[T]he Conseil d'Etat was the child of the revolution of 1789 and the period of the Consulate" while "droit administratif itself was (...) a later development" (Brown and Bell 1998, pp. 9, 4546). The separation between regular and administrative courts was part of 1789 political thought, which sought, given the experience under the Ancien Régime, "to stop the ordinary courts from interfering with the activities of the administration" (Brown and Bell 1998, p. 24). What this meant was the creation of a new format, where "the judges are special judges and the law is a special body of law" (Brown and Bell 1998, p. 44).

This system remains to date: members of the French administrative court system are not lawyers, nor professional judges. The Conseil d'Etat is made of a 300 strong pool of senior, experienced, professional civil servants. It is itself part of the French administration (Brown and Bell 1998, pp. 79, 82-83). In adjudicating, they follow a procedure that is "quite unlike any court procedure in England and differs also from that before the civil courts in France" (Brown and Bell 1998, pp. 89-90). The purpose of this litigation "is first and foremost about enabling the proper functioning of the administration in the principle activity of serving the public rather than control of the administration" (Bell et al. 2008, p. 168). Moreover, adjudication is only part of their job: they also provide expert advice to the government on proposed legislation and policy decisions and perform additional functions outside their role in the court (Brown and Bell 1998, pp. 62-67, 75, 79). 
Another unique feature is their jurisdiction: it covers a wide range of actions - everything that is considered public service or public function (Bell et al. 2008, p. $168 \mathrm{ff}$ ). This means that French administrative courts have jurisdictions not only on what common lawyers consider administrative law - action concerning the misuse of official power - but essentially over any case concerning public interest, including ordinary tort and contract cases. Such cases go before a specialized tribunal whose judges, who are part of the administration apply a specialized substantive law, different from that of the general (and lawyerly) court system. (Brown and Bell 1998, pp. 175-213).

Things are very different in England, where, "so the classic doctrine goes, the ordinary courts are competent for the judicial review of acts of administration: the officials of the state do not constitute a separate, privileged class" (van Caenegem 2002, p. 42). But why is it that England has one general court system which is supposed can handle all types of litigation - including that to which the government is part? To explain this, we need to draw on the convergence-divergence debate - from its origins in the divergent AngloFrench views of administrative law to more decent developments that seem to draw civil and common law closer.

Firstly, long after the French revolution and the rise of an independent legal discipline of administrative law in civil law countries, England refused to follow suit. The phenomenon is attributed to eminent English scholar Albert Venn Dicey, who, in the very first edition of his influential Law of the Constitution (1885) declared French administrative law "utterly unlike any branch of modern English law (...). In England and in countries which, like the United States, derive their civilization from English sources, the system of administrative law, and the very principles upon which it rests, are in truth unknown" (Dicey 1885). There is extensive writing on what Dicey meant, and whether he was wrong (Brown and Bell 1998, pp. 3-6, Stebbings 2006, p. 109, Künnecke 2007). Indeed, Dicey himself partially backtracked decades later (Dicey 1915) - but the setback on the development of administrative law lasted well into the $20^{\text {th }}$ century (Frankfurter 1938, Schwartz 1953, Stebbings 2006, p. 109, fn 164, Stack 2015).

Secondly, with or without sanction, administrative law evolved in Britain. By the time Dicey was published his treatise, common law courts had centuries of experience in administrative review and special administrative courts were being set up in (Stebbings 2006, Brand and Getzler 2012). In the tribunals where English law developed form into substance: as a reaction to the industrial revolution,

from the 1830s the specialist and largely lay statutory tribunal was conceived and adopted as the principal method of both implementing the new regulatory legislation and resolving disputes, between state and the subject, or between subject and subject. (Stebbings 2006, p. 1)

This practice continues today: tribunals still operate in a wide range of topics, their principal feature being that they operate "in an effective, accessible, expeditious and inexpensive way" (Stebbings 2006, p. 1). Indeed, English scholar John Allison considers the formation of administrative tribunals outside the structure of the ordinary courts as one of the reasons why English law now recognizes the distinction between public and private law. This, Allison views as "a legal transplant to English law, which, because of the accompanying hazards (...) must now be re-assessed" (Allison 2004, pp. 1, 3, 72). Eminent Continental scholar van Caenegem reads the same evidence as suggesting that 
"[a]lthough the contrast with the Continent has greatly diminished in recent years, most notably because of the growth of administrative law and special tribunals (...) it is still a real feature of the common of the civil/common-law divide" (van Caenegem 2002, p. 42 and fn. 7).

Thirdly, the idea of a single court system providing all legal services is more ideal than fact. English courts were only consolidated by the Judicature Acts of the late $19^{\text {th }}$ century (Judicature Acts 2020). These created the now-familiar three-tiered High Courts of London headed, until 2009, by the Judicial Committee of the House of Lords, now by the Supreme Court (Supreme Court of the United Kingdom 2020). Yet even today, the first tier High Court is comprised of specialist sections, each component reflecting its original independent ancestor and its jurisdiction: The Queen's Bench Division (QBD), the Chancery Division, and the Family Division (High Court of Justice 2020). The QBD has the most judges (over 70) and the most varied jurisdiction (Queen's Bench 2020), including that of administrative review. The administrative Court has "the power to oversee the quality and legality of the decision-making of the lower courts and tribunals, and hears applications for judicial review of decisions of public bodies" (Judicial Office Communications Team n.d.-a). Is there really such a big difference if specialist courts are inside or outside the formal construct of the general court system? When we see that common law administrative judges operate in a specialist section within the general court system is it not fair to say that cases concerning complaints against officials are heard before a unique forum?

Finally, French administrative courts provided judicial relief (as opposed to equitable relief) in tort and contract cases, before their common law colleagues (Brown and Bell 1998, p. 184, Seidman 2005). Even the United States held long to sovereign immunity. Congress gradually and partially waived sovereign immunity for contracts and torts (in the Tucker Act of 1887 and the Federal Tort Claims Act of 1946, respectively), and established a non-Article III specialist federal court to deal with such claims (Article III appellate court is now available; Sisk 2003). Even when common law jurisdiction allows lawsuits against the government, the substantive private law applied can differ from that applied between two private parties in both contracts (Hadfield 1999, Fissell 2013) and torts (see, e.g., the Israeli Civil Wrongs (Liability of the State) Law, 5712-1952).

How administrative review became part of the general jurisdiction of high courts is well known; less familiar is the story of how and why administrative law tribunals were created, and were located among the lower court. Here is a sketch of the history, followed by examples from England, Israel and the United States.

\section{b. The Evolution and Status of English Administrative Tribunals}

The 'interventionist state' has its origins in $19^{\text {th }}$ century England, and administrative tribunals are one of its prime tools. These tribunals were set up as an organ of the executive, in order to implement a statutory regime (Stebbings 2006, pp. 8, 73-74). The earliest administrative tribunal - and possibly the model for all others - were commissioners entrusted in 1799 with the implementation of tax legislation (Stebbings 2006, pp. 34-36).

It was decided not to use the English court system. While it was familiar and authoritative it turned out that its judges were not accustomed to deciding questions of 
fact (typically left to juries) and that its jurisdiction was unclear (regulatory legislation began in the 1830s, decades before the courts were unified) (Stebbings 2006, pp. 41-42). Moreover: "the process in the superior court of law was notoriously technical, complex with demanding standards of proof and evidence" (Stebbings 2006, p. 42) and superior court judges felt that "adjudication of small administrative factual disputes was beneath them" (Stebbings 2006, p. 44). As for the lower courts: before the $19^{\text {th }}$ century most civil and criminal cases were decided in either local, county courts - created for the benefit of poorer litigants - or special courts. The problem was that the former were already overburdened and their judges lacked he technical skills required to implement the new legislative schemes, while the latter were too specialized. Even the lay - but respectable - justices of the peace were not picked for administrative adjudication, as it was feared that being landowning persons of high-status, they will be conservative and independent (Stebbings 2006, pp. 46-49).

What emerged in the mid-19 ${ }^{\text {th }}$ century was a hybrid institution: a statutory tribunal with judicial processes, clear jurisdiction, expert lay members and legal advice (Stebbings 2006, p. 68). There was appeal or review by the courts (Stebbings 2006, pp. 229-250, 250272) as it remains in Israeli law today. Yet giving adjudicatory powers to tribunals challenged the accepted constitutional theories especially of the rule of law. which. Which is why Dicey (1915), still objected to "such transference of authority" to administrative tribunals (Dicey 1915, p. 150, Stebbings 2006, pp. 105, 108). Amazingly, as late as 2008 common law administrative tribunals were said to "occupy an inherently ambiguous position in system of law and administration" (Smyth 2008).

Decades of recent deliberation finally brought about the Tribunals, Courts and Enforcement Act 2007. The act systematically reorganized tribunals into two uniform institutions: for a first tier, English law likely followed Australia, whose "federal government pioneered the 'super-tribunal,' in which the majority of review rights against government decisions are exercised by one tribunal, the Administrative Appeals Tribunals, divided into divisions" (Carnwath et al. 2008). A second tier is primarily (but not exclusively) an appellate tribunal from the first-tier tribunal on points of law and with permission (2007 Act, §12 \& Background Note, § 13, Gething and Barker 2009). It is a "superior court of record", presided over by the Senior President, with a possibility for appeal to the Court of Appeal, then to the Supreme Court (Carnwath 2011).

Adjudicators in the two tiers of administrative tribunals include both laymen and jurists except that the 2007 act denotes all legally qualified members "tribunal judges", and laymembers - "tribunal members". The 2007 act also confirms the independence of the tribunal judiciary, protected by the same statutory guarantees as their court colleagues. Justice Carnwath (2011), who became the first Senior President of Tribunals in 2007, views this as establishing "tribunals as part of the judicial system, rather than an appendage of the administration", a "trend of assimilation," as Carnwath calls it, which became more apparent when the British government amalgamated the Court Service and the Tribunals Service into one body (GOV.UK 2019).

\section{c. Courts and tribunals - the Israeli example}

The Israeli Court system was formed a century ago, by the British, who received a mandate over the region after World War I (Brun 2008). The legal charter that established the mandatory government was the Palestine Order-in-Council, 1922 (1922 Order). It set 
up a three-tier court system ( $\S \S 39,40 \& 43$ ), which still forms the core of the Israeli court system. The court of first instance in civil and criminal matters is either the Magistrates' or the District court, depending of the monetary sum or severity of the alleged crime. Today, under $\S 51$ of the Courts Law (Consolidated Version) 5744-1984, the threshold for first tier filing at the Magistrates' court is, generally, a civil case valued at up to 2.5 million shekels (ca. 625,000 €) or a criminal matter is punishable with up to 7 years of incarceration. Matters above these significant levels are filed in a District Court. As Israeli law provide one appeal by right, a case filed at the Magistrates' court as first tier is appealed to the District courts (and can reach the Supreme Court on a second appeal by permission only), and a case originating in the District court goes on appeal to the Supreme Court which thus became the main appellate court. Under the mandatory design, the Supreme Court sitting as a High Court of Justice was designated as the first and only instance for administrative review (Sagy 2004, 2014), and final judicial authority was reserved to the Privy Council in London.

The 1922 Order allowed for religious courts in family law. A holdover from Ottoman rule, these courts were originally established in an effort to give religious minorities autonomy in their religious, ritual, charitable and educational affairs. Under the British, the jurisdiction of Islamic courts, the state courts under the Ottomans, was similarly limited to family law (Abu Jaber 1967, Tsimhoni 1984, Abou Ramadan 2015).

After Israeli independence (1948), the Supreme Court became the highest and final instance, but the judiciary remained structurally little changed. The constitutional-level Basic Law: The Judiciary of 1984 recognizes as vested with the power of adjudication the Courts (the Supreme Court; District Courts; Magistrates' Courts; and, in principle, any other court designated by statute as a court of law) and tribunals (religious courts, other tribunals, or other authority, as prescribed by statute) $(\S 1)$. In practice, the term "court" is reserved, for the three tiers of the general system. All other adjudicatory entities are termed "tribunals" (Beit-Din). The term "judge" (shofet) is attributed only to the adjudicators of the general system and those of the military and labor tribunals.

There are three senior tribunal systems: the religious tribunals (Sezgin 2010); the military tribunals, established in 1955 to adjudicate servicemembers (a separate military court system operates in the West Bank and operated in the past in Gaza: Hajjar 2005); and the labor tribunals, set up 1969 under the influence of civil law (Mundlak 2007, 2009). These two-tiered, specialized, professional tribunals (albeit with lay participation) are subject to review by appeal or petition by Israeli Supreme Court); only labor tribunal judges face the same prerequisites and appointment process as the judges of the general court system and enjoy the same renumeration, job security and institutional independence; but adjudicators in the military and religious tribunals enjoy similar conditions. This is why I refer to these three tribunals as the "senior" ones, and why I think they all fall under the European report's definition of court and should be counted in the official Israeli state report.

Other tribunals in Israel that are much closer to the $19^{\text {th }}$ century English model with lay members and greater flexibility with evidence and procedures than courts have. These were first set up by the Mandatory Government, bit-by-bit, without system or design, to deal with specific types of litigation. In some instances, review of administrative action 
was made available not by a tribunal by appeal to a more senior administrative agency, typically to the High Commissioner (Zamir 1999, pp. 89, 93-94).

After Israeli independence well over a hundred tribunals were set up to help the modern welfare state function. (Zamir 1999, pp. 94-95 and fn. 14). The Administrative Tribunals Act, 1992-5752 enacted in an effort to increase uniformity and cohesion among the tribunals, provided a partial solution. The Act established some rules on the structure, membership, evidence, procedure and even extent of substantive review of administrative tribunals, but these are often open-ended. The Act reiterates Basic Law: The Judiciary's promise of adjudicator independence but offers no assurances to tribunal members, who are not professional judges but typically lay civil servants. More significantly, the act is only applicable to the specific tribunals listed in its appendix currently 28tribunals, the most recent, added June 2020, hears employers' challenges of government employee retention grants made during the first COVID-19 shutdown.

What about all other tribunals - whose numbers, workings, caseload, are not clearly known? For them, explains Zamir, the law remains as it was before the administrative tribunals act (Zamir 1999, p. 95), which is vaguer than vague.

On its face, public law is given very strong protection in Israel given the lucky historical quirk that makes it possible for virtually anyone to petition the Israeli Supreme Court directly for redress of grievances allegedly carried out by any official (including judges), the fact that the Court still hears a large number of such petitions annually and that it has power of review over all lower courts and tribunals. Yet the picture is more complex, and not just because the lower administrative tribunals hear a much greater volume of cases:

First, there is no right to be admitted to a hearing the Supreme Court sitting as a High Court of Justice. As §15(c) of Basic Law: The Judiciary makes clear - there are preconditions for such a hearing: the Supreme Court must find it "necessary to grant relief" in the case "for the sake of justice". -These words make available to the Court traditional equitable maxims concerning the timing of review, standing, justiciability, "clean hands", etc. In addition, the Supreme Court only has residual power, when the matter "is not within the jurisdiction of another court" or tribunal. In principle, the availability of redress in another forum - even a lowly administrative tribunal - bars direct petition to the Supreme Court.

Second, having drawn both accolades and criticism for its judicial activism (Medina 2007, Posner 2008), the Israeli Supreme Court has grown more reticent in recent years in terms of both allowing cases to be heard and ruling in favor of petitioners against government (which it always did anyway in only a fraction of cases).

Finally, the Israeli Supreme Court still hears a large number of first tier petitions annually: in 2018 the Court received 1,727 new direct petitions, handled 2,227 and retained a stock of 1,079. But it worth noting a clear trend of recent decades to reduce the Supreme Court's original docket by pushing cases "downstream", mostly to the Courts of Appeal (from where an appeal lies to the Supreme Court: in 2018 the court received 288 new administrative appeals, handled 309, and retained a stock of 271; Israeli Court System 2018, p. 13). In addition, the Court petition fee was raised significantly in 2002 from 386 to 1,500 shekels, and updated periodically to its current level of 1,819 shekels 
(ca. 450€). While this fee can be waived in appropriate cases, it is a non-trivial bar (Alon 2002, Israeli Judiciary 2019). Finally, the Ministry of Justice is advocating the empowerment of first tier courts to hear administrative petitions - clearly signaling what (at least) government lawyers think of their import.

\section{d. Administrative tribunals in the U.S. - the case of Non-Article-III Judges}

A third model of administrative tribunals is found in United States. It is often said that the U.S. federal court judges are the elite core of judges of the land: what draws top jurists is not the pay - generous for civil servants, though not for top lawyers - and not just their relatively small number, and acceptable case load. It is the significance of the cases their hear, the public status and historic tradition, and the explicit provision of Article III of the U.S. Constitution, that provides them life tenure and prevents reduction in their pay. Another key difference is that about $90 \%$ of state judges must be elected to their office (Shugerman 2012).

Article III clearly states the Supreme Court and any lower courts established under it are the only ones in whom "[t]he judicial Power of the United States, shall be vested". If we the Constitution at face value, there could be no federal official exercising a 'judicial power' who is not an Article III judge. "But from the beginning, we have accepted certain forms of adjudication outside Article III - state courts, most obviously, but also territorial courts, administrative adjudication of public rights, and military tribunals. The question is why" (Baude 2020). Baude, and many other great scholars work hard to try and settle this constitutional puzzle; at the same time, in practice, the "administrative state", however, has crossed this constitutional bridge (and many more) a long time ago (Lawson 1994). There are two noteworthy wrinkles:

First, the primary question was whether taken together, the language of Article III and the separation of powers doctrine mean that the more executive branch(es) of government (the President, under Article II, and Congress, when administering U.S. territories under Article IV) retain no judicial or "quasi-judicial" power meaning that any question of the kind must be referred to federal courts. The wording of Article III supports such a limitation: it seems to imagine a hermetic system that include one Supreme Court and inferior courts established by Congress and vests them with "the judicial power of the United States". But then, burdening these courts with every judicial or quasi-judicial decision would be impracticable. Which is why, when the issue came before the Supreme Court in 1856 the Court affirmed the constitutionality of Non-Article III adjudicators, while maintaining that some (but not all) legal matters are inherently judicial and so suspectable to review by an Article III court (Murray's Lessee (1856), Han 2015).

Today there are several specialized Non-Article III federal court systems: the United States Court of Appeals for the Armed Forces (2020), the United States Court of Federal Claims (2020), both are Article I courts whose judges are appointed for a limited term by the President and Confirmed by the Senate, and the U.S. Territorial Courts, under Article IV (United States Territorial Court 2020). The U.S. Tax court is an Article I federal trial court, specializing in adjudicating federal income tax disputes (United States Tax Court 2020). 
Another important set of adjudicators are the administrative law judges (ALJs) who operate within the executive branch; as non-Article III judges they are in a less advantaged position then their English legally qualified counterparts who were recognized in the 2007 reform as members of the judiciary and guarantees them judicial independence (Administrative Law Judge 2020), although the U.S. Supreme Court has noted on several occasions that the work ALJs perform is functionally equivalent to that of an Article III District Court judge (Freytag v Commissioner (1991)). There are about 2,000 ALJs (and 870 authorized Article III judgeships). They share a statutory framework under the Administrative Procedure Act which permits relatively easy inter-agency comparison and discussion. Their work "dwarfs federal judicial adjudication in volume and variety" (Barnett et al. 2018, p. 1) but represents, in itself,

only a fraction of agencies' adjudicatory hearings. Instead, most administrative hearings are before over 10,000 other adjudicators who go by numerous titles but are often collectively called 'non-ALJ adjudicators,' 'non-ALJ-hearing officers,' 'administrative judges,' or variations of those terms. (Barnett et al. 2018, 1)

Second, perhaps it makes good sense to allow government administrators to conduct some forms of review of a judicial or quasi-judicial nature without the burden of court procedures, especially where review by Federal Courts is potentially available in appeal. But one could argue to the contrary - that the importance of the administration's decision (especially when defined in terms of potential infringement on basic rights) requires a professional, independent judge and full-dress proceedings.

Moreover, I find it surprising that Article III Courts use non-Article III judges to conduct their judicial business. The main example is instructive. U.S. Constitution Article I, §8, cl. 4 authorized Congress to enact "uniform Laws on the subject of Bankruptcies throughout the United States," and Congress has. The problem is that the number of such procedures in a nation of 330 million is huge, certainly, by the standards of the federal judiciary. In the year ending September 30, 2018 the entire first tier of the federal courts, 94 courts in all, heard 356,177 cases. The 90 Bankruptcy Courts alone heard more than twice that: 773,375 cases; and this was the lowest total since 2007 and about half the 2010 peak of 1,538,033 (United States Courts 2018a, 2018e). The U.S. District Courts have jurisdiction over bankruptcy cases, but they also have the to "refer" matters to an Article I bankruptcy court and do so in the great majority of cases (United States Bankruptcy Court 2020). U.S. District court judges are also empowered to use another form of Article I judges, magistrate judges, to assist them in the performance of their duties. Created in 1968, this current magistrate program now has almost as many authorized positions (560) as there are District court judgeships (673) (United States Magistrate Judge 2020, Federal Judicial Center - FJC - n.d.) and its members disposed of over 1.3 million cases and proceedings in 2013. It is also instructive that over 150 Magistrate Judges were later appointed as Article III judges (McCabe 2014).

This is not to say that the use of Article I judges by all branches of the federal government goes unchallenged. For one thing, while the literal reading of Article III as requiring all judicial power to be exercised by Article III Judges has been rejected, no clear theoretical principles have emerged to provide clear limits for such exercise of judicial power by non-Article III judges, although efforts in this direction are ongoing (Pfander 2004). Beyond academia, the issue is not fully settled in courts: thus, the Federal Circuits are 
split on the question whether an Article I magistrate judge (rather than an Article III district judge) can accept a felony guilty plea (Gotfryd 2016, Maguire 2017) and the Supreme Court declared some of bankruptcy judges' statutory "core" jurisdiction unconstitutionally over-broad under Article III (Stern v Marshal (2011), Brubaker 2016).

Similar concerns apply to magistrate judges (Mejia 2016). There is another issue of interest: the same differences between Article III and Non-Article III judges that give rise to concern over their intendancy - their employment on a temporary or episodic basic, their limited duties and salary and the fact they in many cases their decision are not formally final until adopted by agency officials - turns out to be relevant in another Constitutional context: that of the Appointments Clause (U.S. Const. Art. II, § 2, cl. 2). A recent decision held that ALJs judges are senior enough officials to be considered "officers of the United States", and must undergo the constitutional appointment process (Lucia v SEC (2018)).

The point I am trying to make here is that even if these are not called "administrative tribunals", by their logic, they really are. As Prof. Dodge wrote:

The Supreme Court expressly rooted its doctrine in a pragmatic accommodation of the modern administrative state. The Court identified the added value of specialized adjudicators, incorporation of appropriate dispute resolution (ADR) mechanisms, and streamlined procedure as unique benefits of non-III tribunals. (Dodge 2015)

\section{Concluding remarks}

The aim of this paper was to call to the attention of scholars considering whether there is 'too much litigation' the work of common law administrative tribunals. History of judicial design has relegated them to the lower parts of the judiciary and required them to handle a high caseload with limited resources. This is a disconcerting situation, because these tribunals often handle cases that significant individual rights are at stake, and the issue are legally complex.

A complicating factor is the still-relatively low status of administrative rights which still do not enjoy the same measure of legal protection or life, liberty and property interests. Just consider the availability of legal redress to an injured party in property, torts, contracts and criminal law - versus the more limited availability of administrative justice. Public law rights are still considered more privilege, more equity than legal right. Entitlements, the "new property," are still not quite the same in the eyes of the law as "old property" (Super 2013). Thus, we saw equitable bars on the jurisdiction of the Israel Supreme Court, but these also exist in the U.S. (Federal Courts employ equitable avoidance standards concerning timing ("ripeness"), exhausting other remedies, standing, mootness and justiciability, although they are termed "prudential considerations"; Cole 2016) and the U.K. (where the recent Supreme Court decision of the suspension of Parliament is considered a landmark precisely because the Court waved a strong justiciability tradition to make the ruling; Letsas 2019).

The need to revamp administrative tribunals is slowly dawning in common law countries. The most promising effort is the major overhaul of administrative tribunals in England and Australia, which not only unified and streamlined their working but effectively brought then into the fold as part of the general court system, with senior judges partaking in the proceedings at both trial and appellate tiers. Israel has, so far, 
taken only limited steps is an effort to shift the high levels of administrative adjudications from the Supreme Court, where petitions historically landed - way down the ranks, from the appellate to the trial courts, then down-under, from the established specialized tribunals and statutorily recognized administrative tribunals to the littleknown administrative tribunals, who leave no record.

In the United States, criticism of non-Article III tribunals is strengthening. Lawson (2017) is worried that the US administrative tribunal adjudication system falls short of constitutional due process requirement and, with Calabresi (2018), is troubled that ALJs share office space with the same agency personnel who initially hear the administrative law cases, and find this a violation of constitutional separation of powers principles. Michael Rappaport (2018) is concerned about ALJs' limited independence and Kent Burnett (2016) wrote a whole string of articles calling for greater attention to administrative adjudicators. So far, such calls for reform and structural improvements (Baum 2010) go unheeded. Interestingly, this is hardly a new concern: already in 1906(!) Professor Harold Bowman (1906) complained that the important maxim that every man is entitled to his day in court, which embodied the safeguards of civil liberty in America

is false. For in the United States we have a body of administrative tribunals, not courts, whose decisions are in many instances as final as those of the regular judicial establishments. They limit liberty and control property; and in matters in which their decisions are final, the day in court becomes a day in the presence of administrative authorities only.

\section{References}

Abou Ramadan, M., 2015. Islamic Legal Hybridity and Patriarchal Liberalism in the Shari' a Courts in Israel. Journal of Levantine Studies [online], 4(2), 39. Available from: https://levantine-journal.org/product/islamic-legal-hybridity-andpatriarchal-liberalism-in-the-sharia-courts-in-israel/ [Accessed 10 November 2020].

Abu Jaber, K.S., 1967. The Millet System in the Nineteenth-Century Ottoman Empire. The Muslim World [online], 57(3), 212-223. Available from: https://doi.org/10.1111/j.1478-1913.1967.tb01260.x [Accessed 10 November 2020].

Administrative Appeals Tribunal (AAT), no date. Who we are. About the AAT [online]. Commonwealth of Australia. Available from: https://www.aat.gov.au/about-theaat/who-we-are [Accessed 10 November 2020].

Administrative Law Judge, 2020. Wikipedia [online], 30 September. Available from: https://en.wikipedia.org/wiki/Administrative law judge [Accessed 10 November 2020].

Allison, J.W.F., 2004. A Continental Distinction in the Common Law - A Historical and Comparative Perspective on English Public Law. Oxford University Press, 1, 3, 72.

Alon, G., 2002. Vaadat Hachuka he'elta et taarif ha'agra lehagashat Bagaz le-1,500 shekel [Law and Justice Committee Raises the Tariff Fee for Submitting a Petition to the High Court of Justice to 1,500 shekels]. Ha'aretz [online], 26 July. Available from: https://www.haaretz.co.il/misc/1.812584 [Accessed 23 November 2020]. 
Aronson, O., 2010. Out of Many: Military Commissions, Religious Tribunals, and the Democratic Virtues of Court Specialization. Virginia Journal of International Law [online], 51(2), 231. Available from: https://ssrn.com/abstract=1651150 [Accessed 10 November 2020].

Australian Government Productivity Commission, 2018. Chapter 7, Courts. In: Report on Government Services, 2018 [online]. Available from:

https://www.pc.gov.au/research/ongoing/report-on-governmentservices/2018/justice/courts/rogs-2018-partc-chapter7.pdf [Accessed 10 November 2020].

Barnett, K., et al., 2018. Draft Report - Non-ALJ Adjudicators in Federal Agencies: Status, Selection, Oversight and Removal [online]. Administrative Conference of the United States, 14 February. Available from:

https://www.acus.gov/sites/default/files/documents/NonALJ\%20Draft\%20Report_2.pdf [Accessed 10 November 2020].

Baude, W., 2020. Adjudication Outside of Article III. Harvard Law Review [online], 133, 1511, 1513. Available from: https://harvardlawreview.org/2020/03/adjudicationoutside-article-iii/ [Accessed 10 November 2020].

Baum, L., 2010. Judicial Specialization and the Adjudication of Immigration Cases. Duke Law Journal [online], 59(8), 1501. Available from: https://core.ac.uk/download/pdf/62548478.pdf [Accessed 10 November 2020].

Bell, J., Boyron, S., and Whittaker, S., 2008. Principles of French Law. $2^{\text {nd }}$ ed. Oxford University Press.

Bendery, J., 2015. Federal Judges Are Burned Out, Overworked and Wondering Where Congress Is. Huffpost [online], 30 September. Available from:

https://www.huffpost.com/entry/judge-federal-courtsvacancies n 55d77721e4b0a40aa3aaf14b?guccounter $=1 \&$ guce referrer $=$ aHR0cHM 6Ly93d3cuZ29vZ2xlLmNvbS8\&guce referrer sig=AQAAAAUA48StV8ew7S8dkJ mFm55UUUU4tchN7TLgZGuZoo9XGocSINa8o71c VlKSPakdDXNN1tnu9nerMt 9VfAlbxi4NjC6RmSx3-KLhsyagcp0xK5OGC5ou32GaOwoSGNdgoHBNmV6dRxISAxqexhrjit1AkMWRY9SjdFD AGgS oZ [Accessed 10 November 2020].

Bentata, P., Espinosa, R., and Hiriart, Y., 2019. Correction Activities by France's Supreme Courts and Control over their Dockets. Revue d'économie politique [online], 129(2), 169.

Bowman, H.M., 1906. American Administrative Tribunals. Political Science Quarterly [online], 21(4), 609. Available from: https://doi.org/10.2307/2141149 [Accessed 10 November 2020].

Brand, P., and Getzler, J., eds., 2012. Judges and Judging in the History of the Common Law and Civil Law: From Antiquity to Modern Times. Cambridge University Press.

Brown, L.N., and Bell, J.S., 1998. French Administrative Law. $5^{\text {th }}$ ed. Oxford: Clarendon Press. 
Brubaker, R., 2016. Non-Article III Adjudication: Bankruptcy, with and without litigant Consent. Emory Bankruptcy Developments Journal, 33, 11.

Brun, N., 2008. Shoftim ve'Mishpetanim Be'Erez Israel - bein Kushta le-Yerushalaim, 19001930 [Judges and Lawyers in Eretz-Israel - Between Constantinople and Jerusalem, 1900-1930]. Jerusalem: Magnes Press.

Burnett, K., 2016. Against Administrative Judges. U.C. Davis Law Review, 49, 1643.

Calabresi, S.G., and Lawson, G., 2007. The Unitary Executive, Jurisdiction Stripping, and the Hamdan Opinion: A Textualist Response to Justice Scalia. Columbia Law Review, 107, 1002, 1015ff.

Calabresi, S.G., and Lawson, G., 2018. The Depravity of the 1930s and the Modern Administrative State. Notre Dame Law Review [online], 94(2), 821, 861-862. Available from: http://ndlawreview.org/wp-content/uploads/2019/01/7-CalabresiLawson.pdf [Accessed 10 November 2020].

Carnwath, R., 2011. Tribunals and the Courts - The UK Model. Canadian Journal of Administrative Law \& Practice, 24, 5-6.

Carnwath, R., et al., 2008. An Overview of the Tribunal Scenes in Australia, Canada, New Zealand and the United Kingdom. In: R. Creyke, ed., Tribunals in the Common Law World. Sydney: The Federation Press, 1.

Central Bureau of Statistics (CBS), 2018. Table 11.2 - Judges, Judges in Rabbinical Courts, Lawyers, Israel Police and Prison Service. CBS [online], 4 September. Available from:

https://www.cbs.gov.il/he/publications/DocLib/2018/11.ShnatonCrimeandJustice/ st11 02.pdf [Accessed 10 November 2020].

Chandrachud, C., 2015. Declarations of Unconstitutionality in India and the U.K.: Comparing the Space for Political Response. Georgia Journal of International and Comparative Law, 43(2), 309-381.

Cole, J.P., 2016. An Introduction to Judicial Review of Federal Agency Action. CRS Report [online]. Congressional Research Service, 7 December. Available from: https://fas.org/sgp/crs/misc/R44699.pdf [Accessed 10 November 2020].

Cour de cassation, 2018. Rapport Annuel 2017 [online]. Paris: Direction de l'information légale et administrative, p. 326. Available from:

https://www.courdecassation.fr/IMG/pdf/rapport2017.pdf [Accessed 10 November 2020].

Courts of England and Wales, 2020. Wikipedia [online], 30 September. Available from: https://en.wikipedia.org/wiki/Courts of England and Wales [Accessed 10 November 2020].

Crown Court, 2020. Wikipedia [online], 9 October. Available from: https://en.wikipedia.org/wiki/Crown_Court [Accessed 10 November 2020].

Decker, K., Möhlen, C., and Varela, D.F., 2011. Improving the Performance of Justice Institutions: Recent Experience from selected OECD Countries relevant for Latin America [online]. The International Bank for Reconstruction and 
Development/The World Bank. Available from:

https://openknowledge.worldbank.org/handle/10986/27451 [Accessed 10

November 2020].

Dicey, A.V., 1885. Lectures Introductory to the Study of the Law of the Constitution [online]. $1^{\text {st }}$ ed. London: Macmillan. Available from:

https://archive.org/stream/lecturesintrodu03dicegoog\#page/n14/mode/2up [Accessed 10 November 2020].

Dicey, A.V., 1915. Administrative Law in England. Law Quarterly Review, 31, 148.

Dodge, J., 2015. Reconceptualizing Non-Article III Tribunals, Minnesota Law Review [online], 99, 905, 906. Available from: https://www.minnesotalawreview.org/wpcontent/uploads/2015/02/Dodge Final.pdf [Accessed 10 November 2020].

Elliott, M., and Thomas, R., 2012. Tribunal justice and proportionate dispute resolution. Cambridge Law Journal [online], 71(2), 297-298. Available from: https://doi.org/10.1017/S0008197312000505 [Accessed 10 November 2020].

European Commission for the Efficiency of Justice (CEPEJ), 2018. Report on "European judicial systems. Efficiency and quality of justice", Study № 26 [online]. Strasbourg: CEPEJ. Available from: https://rm.coe.int/rapport-avec-couv-18-09-2018en/16808def9c [Accessed 21 September 2020].

European Commission, 2019. The 2019 EU Justice Scoreboard: Communication from the Commission to the European Parliament, the Council, the European Central Bank, the European Economic and Social Committee and the Committee of the Regions (COM(2019) 198/2) [online]. Luxembourg: Publications Office of the European Union. Available from:

https://ec.europa.eu/info/sites/info/files/justice scoreboard 2019 en.pdf [Accessed 10 November 2020].

Fabri, M., 2017. Methodological issues in the comparative analysis of the number of judges, administrative personnel, and court performance collected by the Commission for the Efficiency of Justice of the Council of Europe. Oñati SocioLegal Series [online], 7(4) 616, 618-619, 622-630. Available from: http://opo.iisj.net/index.php/osls/article/viewFile/876/1021 [Accessed 10 November 2020].

Federal Judicial Center (FJC), no date. Magistrate Judgeships. FJC [online]. Available from: https://www.fjc.gov/history/judges/magistrate-judgeships [Accessed 10 November 2020].

Fissell, B.M., 2013. Note: The Dual Standard of Review in Contracts Clause Jurisprudence. Georgetown Law Journal [online], 101, 1089. Available from: https://doi.org/10.2139/ssrn.2122608 [Accessed 10 November 2020].

Flores, A., 2019. The Trump Administration Opened Secretive Tent Courts at the Border. The Public is Not Allowed Inside. Buzzfeednews.com, 11 September.

Frankfurter, F., 1938. Foreword. Yale Law Journal [online], 47(4), 515, 517. Available from: https://doi.org/10.2307/791854 [Accessed 10 November 2020]. 
Funken, K., 2003. "The Best of Both Worlds": The Trend Towards Convergence of the Civil Law and the Common System [online]. LA732 Comparative Legal Essay. Available from: https://dx.doi.org/10.2139/ssrn.476461 [Accessed 10 November 2020].

Genn, G., 1993. Tribunals and Informal Justice. The Modern Law Review [online], 56(3), 393, 394. Available from: https://doi.org/10.1111/j.1468-2230.1993.tb02680.x [Accessed 10 November 2020].

Gething, H., and Barker, J., 2009. The Upper Tribunal's power to make determinations of fact on appeal from the First-tier Tribunal. British Tax Review, 54, 351.

Goodnow, D., 2011. A comment from the Chair. In: R. LaFountain et al., Examining the Work of State Courts: An Analysis of 2009 State Court Caseloads [online]. National Center for State Courts. Available from: http://www.courtstatistics.org/ data/assets/pdf file/0024/29805/2009-EWSC.pdf [Accessed 10 November 2020].

Gotfryd, A., 2016. Note: The Safeguards of the Constitution: Fundamental Rights not Disposable Gifts. University of Illinois Law Review [online], no 2, 627. Available from: https://illinoislawreview.org/print/volume-2016-issue-2/the-safeguards-ofthe-constitution-fundamental-rights-not-disposable-gifts/ [Accessed 10 November 2020].

GOV.UK, 2019. HM Courts \& Tribunals Service. GOV.UK [online]. Available from: https://www.gov.uk/government/organisations/hm-courts-and-tribunals-service [Accessed 10 November 2020].

Hadfield, G., 1999. Of Sovereign Immunity and Contract: Damages for Breach of Contract by Government. Southern California Interdisciplinary Law Journal, 8, 467.

Hailbronner, M., 2014. Rethinking the rise of the German Constitutional Court: From anti-Nazism to value formalism. International Journal of Constitutional Law [online], 12(3), 626. Available from: https://doi.org/10.1093/icon/mou047 [Accessed 10 November 2020].

Hajjar, L., 2005. Courting Conflict: The Israeli military court system in the West Bank and Gaza. Berkeley: University of California Press.

Han, H., 2015. Redefining Non-Article III Adjudicatory Authority post-Stern v. Marshall. University of Pennsylvania Journal of Constitutional Law [online], 18, 725, p. 727ff. Available from:

https://scholarship.law.upenn.edu/cgi/viewcontent.cgi?article=1590\&context=jcl [Accessed 10 November 2020].

Henderson, E.G., 1963. Foundations of English Administrative Law. Cambridge, MA: Harvard University Press.

High Court of Australia, 2018. Annual Report 2017-18 [online]. Kingston: High Court of Australia. Available from: https://www.hcourt.gov.au/assets/corporate/annualreports/HCA_Annual_Report 2017-18.pdf [Accessed 10 November 2020].

High Court of Justice, 2020. Wikipedia [online], 23 October. Available from: https://en.wikipedia.org/wiki/High_Court_of_Justice [Accessed 10 November 2020]. 
HM Courts \& Tribunals Service, 2019. UK Tribunal Data - Q4 2018-2019 [online]. UK Government Publishing Service. Available from:

https://assets.publishing.service.gov.uk/government/uploads/system/uploads/att achment data/file/808151/Main Tables_Q4 2018-19.ods [Accessed 10 November 2020].

Israeli Court System, 2018. Doach Shnati 2018 [Annual report 2018] (online). Available from: https://www.gov.il/BlobFolder/reports/statistics annual 2018/he/2018.pdf [Accessed 23 November 2020].

Israeli Judiciary, 2019. Ho'daot Batei Hamishpat - Agrot' [Courts Announcements - Fees] (online), 1.2019. Available from:

https://www.gov.il/he/departments/general/fees_16 [Accessed 23 November 2020].

Judicature Acts, 2020. Wikipedia [online], 1 July. Available from: https://en.wikipedia.org/wiki/Judicature_Acts [Accessed 10 November 2020].

Judicial Office Communications Team, no date-a. President of the Queen's Bench Division. Judiciary [online]. London: Judicial Office. Available from: https://www.judiciary.uk/about-the-judiciary/who-are-the-judiciary/judicialroles/judges/profile-pqbd/ [Accessed 10 November 2020].

Judicial Office Communications Team, no date-b. Senior Judiciary [online]. London: Judicial Office. Available from: https://www.judiciary.uk/about-thejudiciary/who-are-the-judiciary/judicial-roles/judges/profile-pqbd/ [Accessed 10 November 2020].

Judicial Office International Team, 2018. The Judicial System of England and Wales - A visitor's guide (2018) [online], 34. Available from: https://www.judiciary.uk/wpcontent/uploads/2016/05/international-visitors-guide-10a.pdf [Accessed 10 November 2020].

Judiciary of Australia, 2020. Wikipedia [online], 7 September. Available from: https://en.wikipedia.org/wiki/Judiciary of Australia [Accessed 10 November 2020].

Kleiman, M., et al., 2017. Case Weighting as a Common Yardstick: A Comparative Review of Current Uses and Future Directions. Oñati Socio-Legal Series [online], 7(4), 640-660. Available from: http://opo.iisj.net/index.php/osls/article/viewFile/824/1022 [Accessed 10 November 2020].

Künnecke, M., 2007. Tradition and Change in Administrative Law: An Anglo-German Comparison. Berlin: Springer, 16-18.

Lawson, G., 1994. The Rise and Rise of the Administrative State. Harvard Law Review [online], 107(6), 1231-1254. Available from: https://doi.org/10.2307/1341842 [Accessed 10 November 2020].

Lawson, G., 2007. Mostly Unconstitutional: The Case Against Precedent Revisited. Ave Maria Law Review [online], 5, 1. Available from:

https://scholarship.law.bu.edu/faculty scholarship/475?utm source=scholarship.1 
aw.bu.edu\%2Ffaculty scholarship $\% 2 F 475 \& u t m$ medium=PDF\&utm campaign= PDFCoverPages [Accessed 10 November 2020].

Lawson, G., 2017. Take the Fifth... Please! The Original Insignificance of the Fifth Amendment's Due Process of Law Clause. Brigham Young University Law Review [online], no 3, 611. Available from:

https://digitalcommons.law.byu.edu/lawreview/vol2017/iss3/5 [Accessed 10 November 2020].

Letsas, G., 2019. Non-Justiciability of Prorogation: A Matter of Law and Logic? UK Constitutional Law Association [online], 19 September. Available from: https://ukconstitutionallaw.org/2019/09/19/george-letsas-non-justiciability-ofprorogation-a-matter-of-law-and-logic/ [Accessed 10 November 2020].

Lundmark, T., 2012. Charting the Divide between Common and Civil Law. Oxford University Press.

Lustig, D., and Weiler, J.H.H, 2018. Judicial review in the contemporary world Retrospective and prospective. International Journal of Constitutional Law [online], 16(2), 315-372. Available from: https://doi.org/10.1093/icon/moy057 [Accessed 10 November 2020].

Maguire, S J., 2017. Note: Too Much of a Stretch: Why Acceptance of Felony Guilty Pleas by Federal Magistrates defies the Intent of Congress and Erodes the Rights of the Accused Regardless of Consent. Drexel Law Review Online [online], 9, 31. Available from: https://drexel.edu/law/lawreview/issues/Archives/v9web/maguire/ [Accessed 10 November 2020].

Mather, L., 2021. What is a "case"? Oñati Socio-Legal Series [online], 11(2-this issue). Available from: https://doi.org/10.35295/osls.iis1/0000-0000-0000-1149 [Accessed 9 March 2021].

McCabe, P.G., 2014. A Brief History of the Federal Magistrate Judges Program. Federal Lawyer [online], 61-JUN, 44. Available from: https://www.fedbar.org/wpcontent/uploads/2014/05/RMJ-feature6-mayjun14-pdf-1.pdf [Accessed 10 November 2020].

Medina, B., 2007. A Response to Richard Posner's Criticism of Aharon Barak's Judicial Activism. Harvard International Law Journal Online [online], 49, 1. Available from: https://doi.org/10.2139/ssrn.992972 [Accessed 10 November 2020].

Mejia, B.P.D., 2016. Magistrates after Arkison \& Wellness: The Outer Limits of Consent. New York University Annual Survey of American Law [online], 71, 509, 510.

Available from: https://annualsurveyofamericanlaw.org/wpcontent/uploads/2017/01/71-3 mejia.pdf [Accessed 10 November 2020].

Merryman, J.H., 1981. On the Convergence (and Divergence) of the Civil Law and the Common Law. Stanford Journal of International Law, 17, 357.

Ministry of Justice, 2019. Tribunal Statistics Quarterly: January to March 2019. London: GOV.UK [online], Crime, justice and law. Available from: https://www.gov.uk/government/statistics/tribunal-statistics-quarterly-januaryto-march-2019 [Accessed 10 November 2020]. 
Mundlak, G., 2007. Fading Corporatism Israel's Labor Law and Industrial Relations in Transition. Ithaca: Cornell University Press, 90ff.

Mundlak, G., 2009. The Israeli System of Labor Law: Sources and Form, Comparative Labor Law \& Policy Journal, 30, 159, 169-172.

Onţanu, A., and Velicogna, M., 2021. The challenge of comparing EU Member States judicial data. Oñati Socio-Legal Series [online], 11(2-this issue). Available from: https://doi.org/10.35295/osls.iisl/0000-0000-0000-1151 [Acessed 9 March 2021].

Pargendler, M., 2018. The Role of the State in Contract Law: The Common-Civil Law Divide. Yale Journal International Law, 43(3), 143.

Pfander, J.E., 2004. Article I Tribunals, Article III Court, and the Judicial Power of the United States. Harvard Law Review [online], 118(2), 643. Available from: https://doi.org/10.2307/4093393

Posner, R., 2008. How Judges Think. Cambridge, MA: Harvard University Press, 327, 362-368.

Queen's Bench, 2020. Wikipedia [online], 23 October. Available from: https://en.wikipedia.org/wiki/Queen\%27s Bench [Accessed 10 November 2020].

Ramseyer, J.M., and Rasmusen, E.B., 2013. Are Americans More Litigious? Some Quantitative Evidence. In: F.H. Buckley, ed., The American Illness: Essays on the Rule of Law. New Haven: Yale University Press, 69, 80.

Randma-Liiv, T., and Connaughton, B., 2005. Public Administration as a Field of Study: Divergence or Convergence in the Light of "Europeanization"? Trames, 9(4), 260.

Rappaport, M.B., 2018. Classic Liberal Administrative Law in a Progressive World. In: M. Todd Henderson, ed., The Cambridge Handbook of Classical Liberal Thought. Cambridge University Press, 105, 141-142.

Rivlin, E., 2012. Israel as a Mixed Jurisdiction. McGill Law Journal [online], 57(4), 781. Available from: https://doi.org/10.7202/1013031ar [Accessed 10 November 2020].

Royal Court of Justice of the United Kingdom, 2017. UK Royal Court of Justice Annual Tables-2017, Table 3.1 [online]. UK Government Publishing Service. Available from:

https://assets.publishing.service.gov.uk/government/uploads/system/uploads/att achment data/file/738615/2017 RCI tables.xlsx [Accessed 10 November 2020].

Sagy, Y., 2004. Le-Maan Hazedek? Al Hakamato shel Beit-Hamishpat Hagavoha Le'Zedek [For the Administration of Justice? on the Establishment of the High Court of Justice of Israel]. Iyunei Mishpat - Tel-Aviv University Law Review, 28, 225-297.

Sagy, Y., 2014. The Missing Link: Legal Historical Institutionalism and the Israeli High Court of Justice. Arizona Journal of International \& Comparative Law [online], 31(3), 703. Available from:

https://law.haifa.ac.il/images/documents/The\%20Missing\%20Link.pdf [Accessed 10 November 2020].

Schwartz, B., 1953. Book Review: Federal Administrative Law. By Urban A. Lavery. University of Pennsylvania Law Review, 101(7), 1092, 1093. 
Seidman, G., 2005. The Origins of Accountability: Everything I know about the Sovereigns' Immunity, I learned from King Henry III. Saint-Louis University Law Journal, 49, 393-480.

Sezgin, Y., 2010. The Israeli Millet System: Examining Legal Pluralism Through Lenses of Nation-Building and Human Rights. Israel Law Review [online], 43(3), 631, 632633. Available from: https://doi.org/10.1017/S0021223700000911 [Accessed 10 November 2020].

Shnoor, B., and Katvan, E., 2017. Court's Precious Time: Transparency, Honor and Judicial Scarce Resources. Oñati Socio-Legal Series [online], 7(4), 825, 828. Available from: http://opo.iisj.net/index.php/osls/article/view/882 [Accessed 10 November 2020].

Shugerman, J.H., 2012. The People's Courts: Pursuing Judicial Independence in America. Cambridge, MA: Harvard University Press.

Singh, M.P., 2001. German Administrative Law in Common Law Perspective. $2^{\text {nd }}$ ed. Berlin: Springer, 192-195.

Sisk, G.C., 2003. The Tapestry Unravels: Statutory Waivers of Sovereign Immunity and Money Claims Against the United States. George Washington Law Review [online], 71, 602, 610. Available from: https://ssrn.com/abstract=722583 [Accessed 10 November 2020].

Smyth, T., 2008. Overview. In: R. Creyke, ed., Tribunals in the Common Law World. Sydney: The Federation Press, ix.

Stack, K.M., 2015. Lessons from the turn of the Twentieth Century for First-Year Courses on Legislation and Regulation. Journal of Legal Education [online], 65(1), 28. Available from: https://ssrn.com/abstract=2670204 [Accessed 10 November 2020].

Stebbings, C., 2006. Legal Foundations of Tribunals in Nineteenth-Century England. Cambridge University Press.

Sturge, G., 2018. Court statistics for England and Wales. Briefing paper $n^{\underline{0}}$ CBP 8372 [online]. House of Commons Library, 16 December. Available from: http://researchbriefings.files.parliament.uk/documents/CBP-8372/CBP-8372.pdf [Accessed 10 November 2020].

Super, D.A., 2013. A New New Property. Columbia Law Review Sidebar [online], vol. 113, 1773. Available from: https://www.columbialawreview.org/wpcontent/uploads/2016/04/Super.pdf [Accessed 10 November 2020].

Supreme Court of the United Kingdom (UKSC), 2018. Annual Report and Accounts 20172018. Accounts presented to the House of Lords [online]. 5 June. Available from: https://www.supremecourt.uk/docs/annual-report-2017-18.pdf [Accessed 10 November 2020].

Supreme Court of the United Kingdom, 2020. Wikipedia [online], 24 October. Available from: https://en.wikipedia.org/wiki/Supreme Court of the United Kingdom [Accessed 10 November 2020]. 
Teller Report, 2019. Overwork in the court: Why the justice looks old. Teller Report [online], 3 May. Available from: https://www.tellerreport.com/post/overwork-inthe-court--why-the-justice-looks-old.HkWKVsFsN.html [Accessed 10 November 2020].

Tsimhoni, D., 1984. The Status of the Arab Christians under the British Mandate in Palestine. Middle Eastern Studies [online], 20(4), 166. Available from: https://doi.org/10.1080/00263208408700605 [Accessed 10 November 2020].

United States Bankruptcy Court, 2020. Wikipedia [online], 18 August. Available from: https://en.wikipedia.org/wiki/United States bankruptcy court [Accessed 10 November 2020].

United States Court of Appeals for the Armed Forces, 2020. Wikipedia [online], 24 October. Available from:

https://en.wikipedia.org/wiki/United States_Court of Appeals for the Armed Forces [Accessed 10 November 2020].

United States Court of Federal Claims, 2020. Wikipedia [online], 26 October. Available from: https://en.wikipedia.org/wiki/United States_Court of Federal_Claims [Accessed 10 November 2020].

United States Courts, 2017. Supreme Court of the United States - Cases on Docket, Disposed of, and Remaining on Docket at Conclusion of October Terms, 2012 Through 2017 [online]. Administrative Office of the U.S. Courts. Available from: https://www.uscourts.gov/sites/default/files/data tables/supcourt a1 0930.2018.p df [Accessed 10 November 2020].

United States Courts, 2018a. Just the Facts: Consumer Bankruptcy Filings, 2006-2017 [online]. Administrative Office of the U.S. Courts. 7 March. Available from: https://www.uscourts.gov/news/2018/03/07/just-facts-consumer-bankruptcyfilings-2006-2017 [Accessed 10 November 2020].

United States Courts, 2018b. Table B. U.S. Courts of Appeals-Cases Commenced, Terminated, and Pending During the 12-Month Periods Ending September 30, 2017 and 2018 [online]. Administrative Office of the U.S. Courts. Available from: https://www.uscourts.gov/sites/default/files/data tables/jb b 0930.2018.pdf [Accessed 10 November 2020].

United States Courts, 2018c. Table C. U.S. District Courts-Civil Cases Commenced, Terminated, and Pending During the 12-Month Periods Ending September 30, 2017 and 2018 [online]. Administrative Office of the U.S. Courts. Available from: https://www.uscourts.gov/sites/default/files/data tables/jb c 0930.2018.pdf [Accessed 10 November 2020].

United States Courts, 2018d. Table D. U.S. District Courts-Criminal Defendants Commenced, Terminated, and Pending (Including Transfers), During the 12-Month Periods Ending September 30, 2017 and 2018 [online]. Administrative Office of the U.S. Courts. Available from: https://www.uscourts.gov/sites/default/files/data tables/jb d 0930.2018.pdf [Accessed 10 November 2020]. 
United States Courts, 2018e. U.S. Bankruptcy Courts - Judicial Business 2018 [online]. Administrative Office of the U.S. Courts. Available from: https://www.uscourts.gov/statistics-reports/us-bankruptcy-courts-judicialbusiness-2018 [Accessed 10 November 2020].

United States Magistrate Judge, 2020. Wikipedia [online], 26 August. Available from: https://en.wikipedia.org/wiki/United States magistrate judge [Accessed 10 November 2020].

United States Tax Court, 2020. Wikipedia [online], 25 October. Available from: https://en.wikipedia.org/wiki/United States Tax Court [Accessed 10 November 2020].

United States Territorial Court, 2020. Wikipedia [online], 9 April. Available from: https://en.wikipedia.org/wiki/United States territorial court [Accessed 10 November 2020].

van Caenegem, R.C., 2002. European Law in the Past and the Future: Unity and Diversity over Two Millennia. Cambridge University Press.

Zamir, Y., 1999. Administrative Tribunals: Establishment, Makeup and Administration. In: Y. Tamir and O. Hirsch, eds., Batei Din Minhalee'im - Hakama, Herkev Veminhal [The Tamir Book]. Tel-Aviv: Bursi (in Hebrew).

Zarchin, T., 2011. Israel First in World for Lawyers per Capita, Study Finds. Ha'aretz [online], 3 August. Available from: https://www.haaretz.com/1.5039519 [Accessed 10 November 2020].

Zer-Gutman, L., 2019. The effects of the shortage of judges in Israel. International Journal of the Legal Profession [online], 26(1), 127. Available from:

https://doi.org/10.1080/09695958.2018.1489819 [Accessed 10 November 2020].

Legal reference

Basic Law: The Judiciary (Israel) [online]. Available from: https://www.knesset.gov.il/laws/special/eng/basic8 eng.htm [Accessed 11 November 2020].

Palestine Order-in-Council, 1922 (1922 Order) [online]. Available from: https://unispal.un.org/DPA/DPR/unispal.nsf/0/C7AAE196F41AA055052565F5005 4E656 [Accessed 11 November 2020].

The (Australian) Administrative Appeals Tribunal Act 1975.

The Administrative Tribunals Act, 1992-5752 (Israel).

The Civil Wrongs (Liability of the State) Law, 5712-1952 (Israel).

The Courts Law (Consolidated Version) 5744-1984 (Israel).

Tribunals, Courts and Enforcement Act 2007. UK Public General Acts, 2007 c. 15. (text of the 2007 Act, and explanatory notes) [online]. Available from: https://www.legislation.gov.uk/ukpga/2007/15/contents [Accessed 11 November 2020]. 


\section{Case law}

Freytag v Commissioner, 501 U.S. 868 (1991) at p. 891.

Lucia v Sec. E Exch. Comm'n, 138 S. Ct. 2044 (2018).

Murray's Lessee v Hoboken Land E Improvement Co., 59 U.S. (18 How.) 272 (1856).

Stern v Marshal, 564 U.S. 462 (2011). 